\title{
Species diversity and abundance of avifauna in the university of agriculture, Benue state, north central Nigeria
}

\begin{abstract}
The main objective of the study was to determine the species composition, relative abundance and species diversity of avifauna found in and around University of Agriculture Makurdi fish ponds. Transect line approach and direct observation methods were deployed for bird's survey. Transect line approach was established using the dykes on the edges of the fish ponds with an interval of $4 \mathrm{~m}$ apart. A pair of binoculars was used for direct observation of birds. Data was collected by carefully walking through the dykes on the edges of the fish ponds, counting the birds seen in and around the fish ponds. A field guide "birds of West Africa" was used for identification of birds. Data were analyzed using paired t-test, non paired $\mathrm{t}$-test and independent $\mathrm{t}$-test to test for the diversity between terrestrial and aquatic birds. Frequency and percentage were used to estimate the relative abundance of each species. A total of 17 species made up of 11 terrestrial and 6 aquatic birds belonging to 14 families were identified. A total of 978 birds comprising of both terrestrial and aquatic birds were recorded in the morning hours. While 988 birds comprising of both terrestrial and aquatic birds were recorded in the morning. Ardeola ibis was the most abundant species $(21.55 \%)$, followed by Streptopelia decipiens $(13.73 \%)$. It was concluded that the birds observed were mainly local species such as Actophilormis africana, Clamator jacobinus, Centropus senegalensis, Ploceus nigerrimus, and many other species. There was no significant difference in the number of terrestrial and aquatic birds observed during the study. Further studies should be conducted to cover wet season and nocturnal birds to generate a comprehensive list of bird species in and around the University fish farm.
\end{abstract}

Keywords: avifauna, predatory bird, species composition, relative abundance, species diversity
Volume 2 Issue 4 - 2018

\author{
Labe TE, Iwar IM, Uloko IJ \\ Department of Wildlife and Range Management, University of \\ Agriculture, Nigeria
}

Correspondence: Labe Terese, Department of Wildlife and Range Management, University of Agriculture, Nigeria, Tel +2340 703। 9117 0, Email labeterese@gmail.com

Received: May 21, 2018 | Published: July 20, 2018

\section{Introduction}

Avifauna is a general name for bird species. Birds are feathered, winged, egg-laying vertebrates. They belong to the Kingdom "Animalia," Phylum Chordata and class Aves. They have a worldwide distribution, living in and around oceans, rivers, forest and mountains. They are the most noticeable group in the animal kingdom. ${ }^{1}$ Their bright colours, distinct songs and calls, and showy displays add fun to human life. Many people derive great pleasure from watching birds and listening to their beautiful songs. Birds are social animals that communicate with visual signs, calls and songs. They display social behaviours such as cooperative breeding and hunting, flocking and mobbing of predators. Birds live and breed in most terrestrial habitats and on all the seven Continents. Nigeria is blessed with many species of birds scattered throughout the different ecological regions.

As with any natural habitat, wetlands are important in supporting bird species diversity. University of Agriculture Makurdi Fish farm is a wetland area that attracts many species of birds. Wetlands provide food for birds in the form of plants, vertebrates, and invertebrates. ${ }^{2}$ Some birds forage for food in the wetland soils, while some find food in the water column and others feed on the vertebrates and invertebrates that live on submerged and emergent plants.

Birds are used as a tool for environmental monitoring. Birds are good biological indicators. They are good indicators of the general state of our biodiversity. When they start disappearing, it means something is wrong with the environment and is a signal that action must be taken. They are suitable for detecting changes in the environment like environmental contaminants and air pollution. Birds detect changes in the environment which cannot be detected or observed by physical parameters. Birds are also good biological control. They consume insect such as mosquitoes, beetles and stem borers which are pests. Without birds reducing the population of these insects, imagine the population of these insect pests that would consume our blood, destroy agricultural crops and forest trees. ${ }^{3}$ Birds have beneficial interactions with forest plants. The beneficial interactions include pollination and seed dispersal. Flowers of some plant species have been discovered to be visited by birds. Humming birds pollinate various nectarproducing plants, transporting pollen on their beaks and feathers from one flower to another. Some birds relocate fish eggs that get stuck to their legs, there by introducing other species of fish to other parts of the river or marsh. Birds have a good system for spreading plant seeds that makes them agents of dispersal. They eat fruits and swallow the seeds of plants. When they dispose of their waste, the seeds are disposed along with it. Bird droppings (feaces) provide good fertility to the soil upon which they are dropped, giving the seeds very good conditions with which to grow.

Bird extinction and population reduction can result to disruption of ecosystem processes that are of great importance to the society. Anderson et al., ${ }^{4}$ maintained that when distinct ecosystems such as forests and wetlands are destroyed, the ecological roles of birds often disappear with them. Habitat loss, over exploitation and increased predators are the causes of decline in population. Extinction of bird species is predicted to continue in the near future, if avian extinction 
is left unabated. The broad objective of the study was to determine the species composition, relative abundance and species diversity of avifauna found in and around University of Agriculture Makurdi fish ponds. The specific objectives were to identify the different water birds that come around the University of Agriculture Makurdi Fish ponds and to estimate the relative abundance of each species.

\section{Methodology}

\section{The study area}

University of Agriculture Makurdi is located in Benue State, North Central Nigeria. The University Fish Farm is located close to river Benue in the South-Core of the University. It was established in 1993 for experimental research.

\section{Method of data collection}

Transect line method was used for the bird survey. This involved moving slowly along the dykes (edges of fish ponds) and recording all birds seen and detected in and around the fish ponds. The survey was carried out at thirty-five (35) fish ponds of the University for a period of three (3) weeks using transect line method. Bird observation was carried out twice daily; morning between 6:00 to 10:00 a.m. and evening between 4:00 to 6:30p.m. by walking slowly along the dykes. Birds were counted as birds seen around the fish ponds and birds in flight were also counted. A pair of binoculars with magnification 7X50 was used for identification of birds visually along side with field guide "Birds of West Africa" for identification of birds. A Sony camera with a zoom lens was used for taking photographs of the birds.

\section{Data analysis}

Data were analyzed using paired t-test, non-paired t-test and independent $\mathrm{t}$-test to test for the diversity between terrestrial and aquatic birds. Frequency and percentage were used to estimate the relative abundance of each species.

\section{Relative Abundance $=\frac{\text { Number of individual Species }}{\text { Total number of all the species }} \times 100$ \\ Results and discussion}

A total of 17 species of birds made up of terrestrial and aquatic species belonging to 14 families were observed in the University of Agriculture Makurdi Fish ponds. The families: Cuculidae, Accepitridae and Ploceidae had two species of birds each. The family Ardeidae, Anatidae, Columbidae, Jacanidae, Ciconiidae, Upupidae, phasanidae, collidae and Alcedinidae had only one specie each (Table $1)$.

Tables $2 \& 3$, shows that there was no significant difference in the number of terrestrial and aquatic birds observed both in the morning and evening. A total number of 519 terrestrial birds were recorded in the morning. 662 terrestrial birds were recorded in the evening. While 316 aquatic birds were recorded in the morning. In the evening, 326 aquatic birds were recorded. Altogether, a total of 978 birds comprising of both terrestrial and aquatic birds were recorded in the morning. While in the evening, a total of 988 birds comprising of both terrestrial and aquatic birds were recorded. This is similar to the findings of Kwaga et al. ${ }^{5}$, It was observed that terrestrial birds were higher in number (11 individuals) than water birds (6 individuals). In Table 4, cattle egret (Ardeola ibis), had the highest relative frequency $(21.55 \%)$ followed by Vinaceous dove (Streptopelia decipiens) $13.73 \%$. black shouldered kite (Elamus caeruleus) $7.80 \%$ and blue- billed malimbe (Malimbus nitens) 7.80\%, Vieillot's black weaver (Ploceus nigerrimus) and bar-breasted mouse bird (Colius macrourus) with $7.09 \%$, black kite (Milvus migrans) had 6.62\%, Actophilormis africana (5.81\%), white necked stork (Ciconia episcopus) 5.67\%, Centropus senegalensis (5.44\%), pied crested cuckoo (Clamator jacobinus) $5.20 \%$. while Anas sparsa and Corvus albus had the lowest relative frequency of $0.95 \%$ each. This is similar to the submission of Bideberi ${ }^{6}$ who reported that the abundance of some bird species could be as a result of habitat type. In Table 1; there was no significant difference in the families of birds observed in the morning and evening. It was observed that University of Agriculture Makurdi fish farm has attracted many local bird species to roost, forage and nest in the area. Most of the birds observed during the study were resident species and no migratory species were species were seen. It was also observed that some birds such as pied king fisher (Ceryle rudis), white necked stork (Ciconia episcopus), lily trotter (Actophilormis africana), black kite (Milvus migrans) were feeding on the fish species like tilapia, clarias, carp and heterobranchus found in the fish ponds. This is similar to the summition of Stewart ${ }^{7}$ who reported that Some birds foraged for food in the wetland soils; some found food in the water column and some fed on the vertebrates and invertebrates that live on submerged and emergent plants. ${ }^{7}$ Also, higher number of terrestrial birds is attributed to the fish farm having greater resources such as food, nesting sites and a resulting ability to support more birds. Wetlands are productive ecosystems and nesting sites for birds. ${ }^{8}$ It was also observed that some birds were feeding on the fruits of Ficus sur which were preferred food for some birds such as vieillot's black weaver (Ploceus nigerrimus) and blue billed malimbe (Malimbus nitens), and resting on trees like sarcocephalus latifolius. Petersen \& Westmark ${ }^{9}$ reported that bird species richness and diversity within wetlands were positively correlated with percentage cover of trees. Lily trotter (Actophilormis africana) was observed resting and feeding on floating vegetation in the fish ponds.

Table I Comparison of birds' families, both morning and evening.

\begin{tabular}{lllll}
\hline Family & Morning & Evening & Frequency & Percentage (\%) \\
\hline Cuculidae & 79 & 97 & 176 & 9.3 \\
Accipitridae & 93 & 100 & 193 & 10.2 \\
Ploceidae & 199 & 214 & 413 & 21.82 \\
Ardeidae & 192 & 216 & 408 & 21.55 \\
Anatidae & 20 & 9 & 29 & 1.53 \\
Columbidae & 113 & 147 & 260 & 13.73 \\
Jacanidae & 53 & 57 & 110 & 5.13 \\
Ciconiidae & 23 & 17 & 40 & 2.11 \\
Rallidae & 7 & 9 & 16 & 0.85 \\
Corvidae & 11 & 3 & 14 & 0.74 \\
Upupidae & 22 & 18 & 40 & 2.11 \\
Phasanidae & 2 & 13 & 140 & 7.4 \\
Collidae & 71 & 69 & 140 & 7.4 \\
Alcedinidae & 21 & 18 & 39 & 2.06 \\
\hline
\end{tabular}

$t=-1.65, d f=13, P=0.12$ 
Table 2 Terrestrial birds observed both morning and evening.

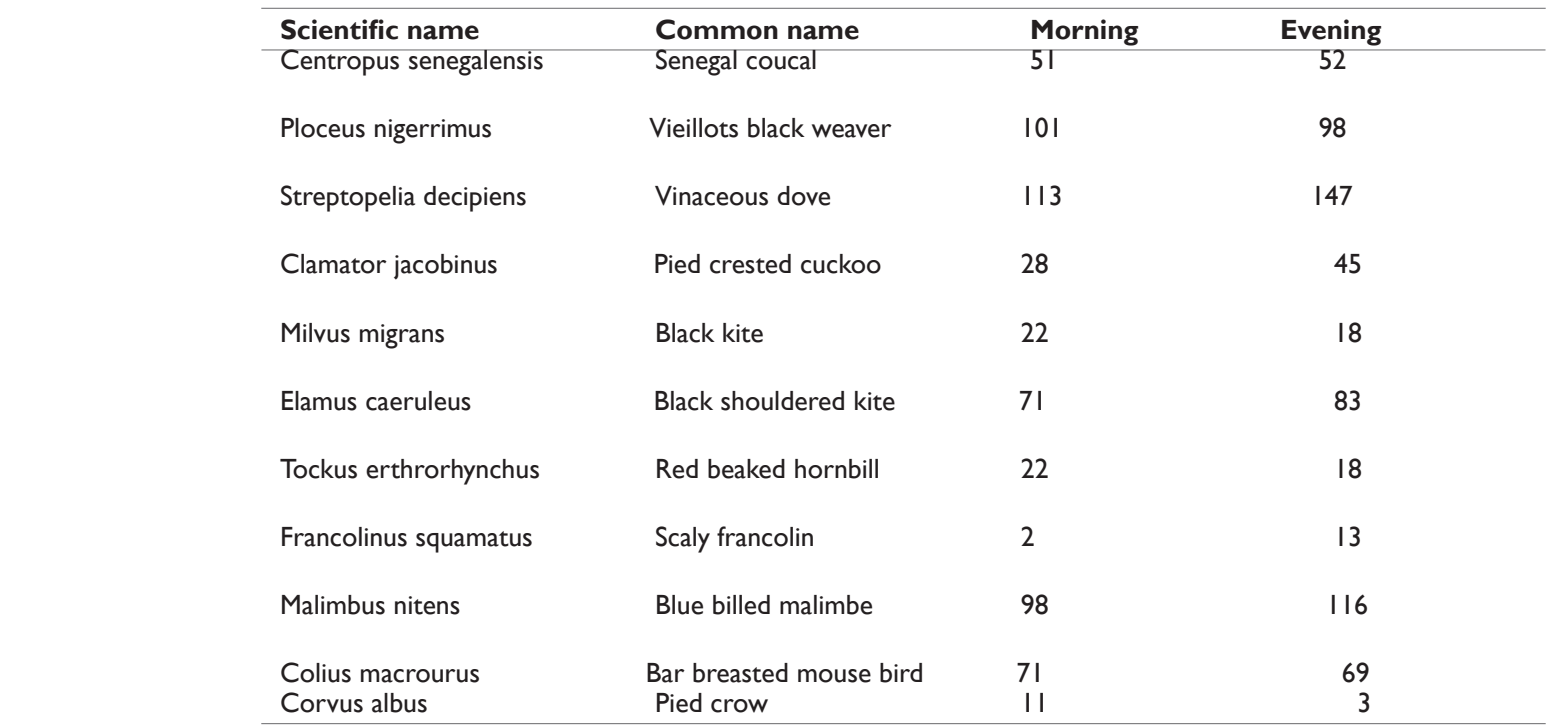

$\mathrm{t}=-0.33, \mathrm{df}=5, \mathrm{P}=0.75$

Table 3 Water birds observed both morning and evening.

\begin{tabular}{llll}
\hline Scientific name & Common name & Morning & Evening \\
\hline Ardeola ibis & Cattle egret & 192 & 216 \\
Actophilormis africana & Lily trotter & 53 & 57 \\
Ciconia episcopis & White necked stork & 23 & 17 \\
Anas sparsa & African black duck & 20 & 9 \\
Ceryle rudis & Pied king fisher & 21 & 18 \\
Limnocorax flavirostra & Black crake & 7 & 9 \\
\hline
\end{tabular}

$\mathrm{t}=-0.33, \mathrm{df}=5, \mathrm{P}=0.75$

Limnocorax flavirostra

Table 4 Relative frequency of each species.

\begin{tabular}{|c|c|c|c|}
\hline \multirow{2}{*}{$\begin{array}{l}\text { Scientific name } \\
\text { Ardeola ibis }\end{array}$} & \multirow{2}{*}{$\begin{array}{l}\text { Common name } \\
\text { Cattle egret }\end{array}$} & \multicolumn{2}{|c|}{ Family Percentage frequency $\%$} \\
\hline & & Ardeidae & 21.55 \\
\hline Actophilormis africana & Lily trotter & Jacanidae & 5.81 \\
\hline Centropus senegalensis & Senegal coucal & Cuculidae & 5.44 \\
\hline Streptopelia decipiens & Vinaceous dove & Columbidae & 13.73 \\
\hline Elamus caeruleus & Black shouldered kite & Accipitridae & 7.80 \\
\hline Malimbus nitens & Blue billed malimbe & Ploceidae & 7.80 \\
\hline Ploceus nigerrimus & Vieillot's black weaver & Ploceidae & 7.09 \\
\hline Colius macrourus & Bar-breasted mouse bird & Collidae & 7.09 \\
\hline Milvus migrans & Black kite & Accipitridae & 6.62 \\
\hline Ciconia episcopus & White necked stork & Ciconiidae & 5.67 \\
\hline Clamator jacobinus & Pied crested cuckoo & Cuculidae & 5.20 \\
\hline Limnocorax favirostra & Black crake & Rallidae & 3.78 \\
\hline Tockus erthrorhynchus & Red beaked hornbill & Upupidae & 2.36 \\
\hline Francolinus squamatus & Scaly francolin & Phasanidae & 1.42 \\
\hline Anas sparsa & African black duck & Anatidae & 0.95 \\
\hline Corvus albus & Pied crow & Corvidae & 0.95 \\
\hline
\end{tabular}

Citation: Labe TE, Iwar IM, Uloko IJ. Species diversity and abundance of avifauna in the university of agriculture, Benue state, north central Nigeria. Forest Res Eng Int J. 2018;2(4):198-202. DOI: 10.15406/freij.2018.02.00048 
The results revealed that 6 bird species dominated the area in terms of relative abundance (Table 5). Cattle egret (Ardeola ibis) is the most dominant $(21.55 \%)$ followed by vinaceous dove (Streptopelia decipiens) $13.73 \%$, blue billed malimbe (Malimbus nitens) $11.30 \%$, vieillot's black weaver (Ploceus nigerrimus) $10.51 \%$, black shouldered kite (Elamus caeruleus) $8.08 \%$, bar-breasted mouse bird (Colius macrourus) $7.40 \%$. The higher abundance of birds in wetlands could be due to the composition of the main elements of their habitats. Table 6 revealed that there was no significant difference between the terrestrial and aquatic birds in terms of bird species diversity. Although, there was a difference in numbers of bird species when making comparisons (Figures 1-4).

Table 5 Birds' species in terms of relative abundance.

\begin{tabular}{llc}
\hline Scientific name & Common name & Relative abundance \\
\hline Ardeola ibis & Cattle egret & 21.55 \\
Streptopelia decipiens & Vinaceous dove & 13.73 \\
Malimbus nitens & Blue billed malimbe & 11.30 \\
Ploceus nigerrimus & Vieillot's black weaver & 10.51 \\
Elamus caeruleus & Black shouldered kite & 8.08 \\
Colius macrourus & Bar-breasted mouse bird & 7.40 \\
Actophilormis africana & Lily trotter & 5.81 \\
Centropus senegalensis & Senegal coucal & 5.44 \\
Clamator jacobinus & Pied crested cuckoo & 3.86 \\
Milvus migrans & Black kite & 2.11 \\
Ciconia episcopus & White necked stork & 2.11 \\
Tockus erthrorhynchus & Red beaked hornbill & 2.11 \\
Ceryle rudis & Pied king fisher & 2.06 \\
Anas sparsa & African black duck & 1.53 \\
Limnocorax flavirostra & Black crake & 0.85 \\
Francolinus squamatus & Scaly francolin & 0.80 \\
Corvus albus & Pied crow & 0.74 \\
\hline
\end{tabular}

Table 6 Terrestrial and aquatic birds compared.

\begin{tabular}{llll}
\hline Terrestrial birds & No & Aquatic birds & No \\
\hline Centropus senegalensis & 103 & Ardeola ibis & 408 \\
Ploceus nigerrimus & 119 & Actophilormis africana & 110 \\
Streptopelia decipiens & 260 & Ciconia episcopus & 40 \\
Clamator jacobinus & 73 & Anas sparsa & 29 \\
Milvus migrans & 40 & Ceryle rudis & 39 \\
Elamus caeruleus & 153 & Limnocorax flavirostra & 16 \\
Tockus erthrorhynchus & 40 & & \\
Francolinus squamatus & 15 & & \\
Malimbus nitens & 214 & & \\
Colius macrourus & 140 & & \\
Corvus albus & 14 & &
\end{tabular}




\section{Some bird species found in UAM fish ponds}

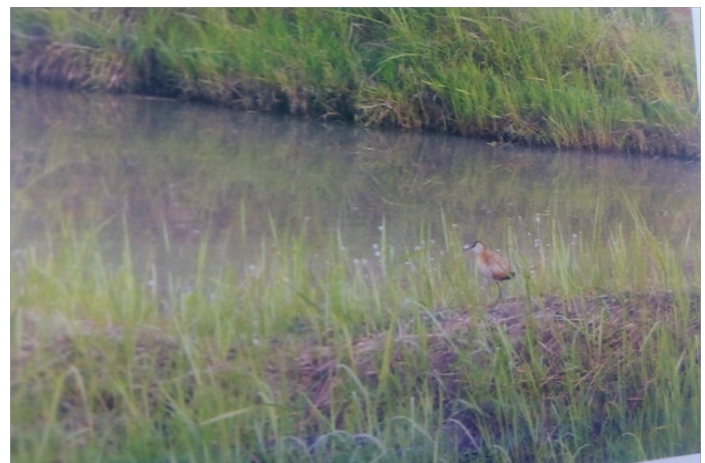

Figure I Lily trotter (Actophilormis africana) around the University of Agriculture Makurdi fish pond.

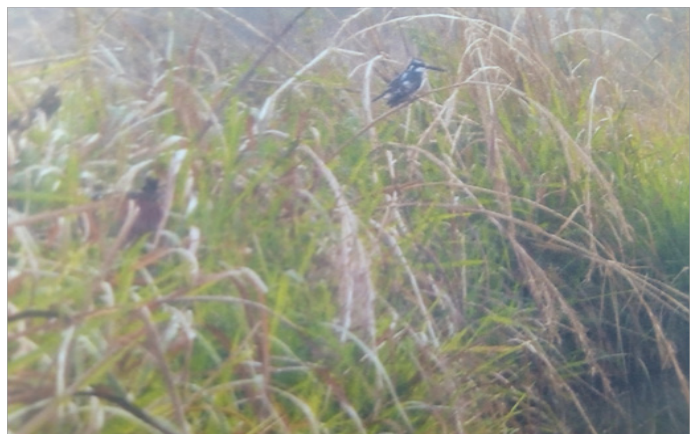

Figure 2 Pied crested cuckoo (Clamator Jacobinus).

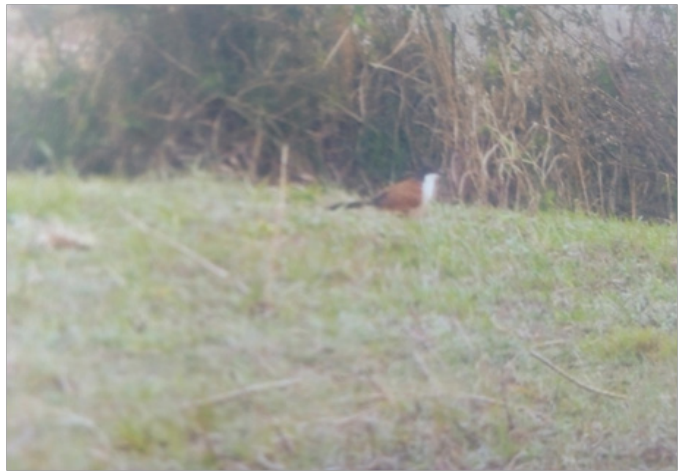

Figure 3 Senegal coucal (Centropus senegalensis).

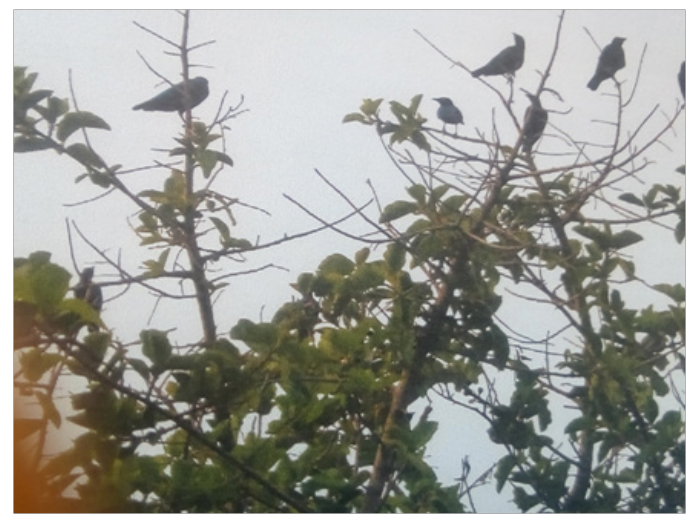

\section{Conclusion}

University of Agriculture Makurdi fish farm is a wetland area that is important for the bird communities. The fish farm has attracted many local bird species to roost, forage and nest in the area. There was no greater variation in species composition and abundance between terrestrial and aquatic birds. There was no significant difference in the number of terrestrial and aquatic birds observed during the study. In overall abundance, Ardeola ibis had the highest relative frequency $(21.55 \%)$ followed by Streptopelia decipiens (13.73\%). The birds observed were mainly local and resident species. The fish farm could have more bird species if human activities are not threatening the life of avifauna.

\section{Acknowledgements}

Further studies to cover wet season and nocturnal birds to document a comprehensive list of bird species around the University of Agriculture Makurdi fish ponds are vital. There should be land use planning that will emphasize bird-friendly landscape design around the University fish farm.

\section{Conflict of interest}

Author declares there is no conflict of interest.

\section{References}

1. Zedler JB. Wetlands at your service: reducing impacts of agriculture at the watershed scale. Frontiers in Ecology and the Environment. 2003;1(2):65-72.

2. Lameed GA. Species diversity and abundance of wild birds in Dagona water fowl sanctuary, Borno State, Nigeria. African Journal of Environmental Science and Technology. 2011;5(10):855-866.

3. Ezealor AU. Important Bird Areas in Africa and Associated Islands. Priority sites for Conservation Series. UK: Pisces Publications; 2001. p. 673-682.

4. Anderson SH, Dave K, Alastair WR, et al. Birds as pollinators and Dispersers: a case study from New Zealand. Acta Zoologica Sinica. 2006;52:112-115.

5. Kwaga BT, LLiya D, Ali A, et al. Avifauna Abundance and Diversity in Jos Wildlife Park, Nigeria. Agricultural Science and Technology. 2017;9(3):234-239.

6. Bideberi G. Diversity, Distribution and Abundance of Avifauna in Respect to Habitat Types: a case study of Kilakala and Bigwa, Morogoro, Tanzania. Tanzania; Sokoine University of Agriculture; 2013. 2 p.

7. Stewart RE. Wetlands as Birds Habitat. United States Geological Survey water Supply Paper. Journal of Natural Biological Service. 2007:24-25.

8. Jannert J. Restoration of Lake Osten, a wetland of International Importance for migrating birds. Tanzania: Report by County Administration of Tanzania Birding Hotspots; 2003.

9. Petersen KL, Westmark AS. Bird use of Wetlands in Midwestern Metropolitan Area in Relation to Adjacent Land Cover. The American Midland Naturalist. 2013;169(1):221-228.

Figure 4 Vieillot's black weaver (Ploceus nigerrimus). 